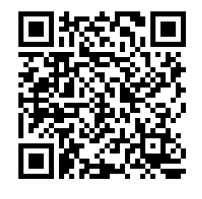

Keywords:

Yield

Kappa number

Eucalyptus

Historic:

Received 18/09/2018

Accepted 21/12/2018

Correspondence: adrianaribeiro_qui@yahoo.com.br
Robisnéa Adriana Ribeirola , Jorge Luiz Colodette ${ }^{\mathrm{lb}}$, Sílvio Vaz Júnior ${ }^{2 c}$

\section{EFFECT OF RESIDUAL EFFECTIVE ALKALI ON EUCALYPTUS KRAFT PULP YIELD AND CHEMISTRY}

RIBEIRO, R. A.; COLODETTE, J. L.; VAZ JÚNIOR, S. Effect of residual effective alkali on eucalyptus kraft pulp yield and chemistry. CERNE, v. 24, n. 4, p. 408-4I9, 2018.

\section{HIGHLIGHTS}

The low-REA cooks showed higher pulp yield, xylan yield, cellulose yield and viscosity.

The lignin-HexA free screen yields were about similar in the kappa range of 18-26.

The low-REA cooks required about $20 \%$ less EA than high-REA ones to achieve the kappa.

Among the various woods, E. globulus was the easiest to delignify.

\section{ABSTRACT}

The impact of residual effective alkali (REA) and pulp delignification degree on Eucalyptus kraft pulp yield and chemistry was investigated. In this study four types of eucalypt clones were evaluated. The eucalypt woods were cooked to kappa numbers of I4 $\pm I, I 8 \pm I$, $22 \pm I$ and $26 \pm I$ using two different ranges of REA, namely: low-REA $\left(I-2 \mathrm{~g} \cdot \mathrm{L}^{-1}\right)$ and highREA (8-9 g. $\left.\mathrm{L}^{-1}\right)$. In general, the low-REA cooks lead to pulps of higher yield, viscosity and xylans content and lower brightness and hexenuronic acid (HexA) content, in relation to the high-REA cooks. In addition, the low-REA cooks required about $20 \%$ less effective alkali to achieve the target kappa, in spite of demanding about $50 \%$ more $\mathrm{H}$-factor. Similar trends were observed for the other woods and kappa values evaluated, but the level of gains varied substantially among woods and delignification degrees. Among the various woods, E. globulus was the easiest to delignify. There was a trend of higher brown pulp yield for the cooks terminated at higher kappa in the range of 14-26, but the lignin-HexA free screen yields were about similar in the kappa range of 18-26 for a given wood type.

' Federal University of Viçosa, Viçosa, Miinas Gerais, Brazil - ORCID: 0000-0002-6063-756Xa, 0000-000 I-6790$6104^{\mathrm{b}}$

${ }^{2}$ Agricultural Research Corporation (Embrapa). Embrapa Agroenergia - ORCID: 0000-000 I-8872-4I82 ${ }^{c}$ 


\section{INTRODUCTION}

Kraft pulping is the most widely used process for production of chemical pulps (Gullichsen \& Fogelholm, 2000). Wood chips are treated with a strong alkaline solution composed mainly of $\mathrm{HO}^{-}$and $\mathrm{HS}^{-}$ions, at temperatures about $150-170^{\circ} \mathrm{C}$ (Pinto, et al., 2005). Several process parameters influence the chemistry and efficiency of alkaline delignification, including time/ temperature $(\mathrm{H}$-factor), effective alkali charge (EA), sulfidity, etc. These parameters affect the characteristics of the resulting pulp regarding the nature and content of its main components, namely: cellulose, hemicelluloses and lignin (Colodette et al., 2002).

During the kraft process, wood delignification is accompanied by simultaneous and undesirable dissolution of carbohydrates mainly by alkaline hydrolysis and sequential elimination of the terminal reducing end groups (Nieminen et al., 2014). Hemicelluloses are more susceptible to alkaline hydrolysis than cellulose due to their low degree of polymerization, amorphous state, and accessibility to the pulping liquor. Therefore, the loss of hemicelluloses is responsible for a significant part of the total yield loss observed during Kraft pulping (Clark, 1985; Sjöström, 1993). The main hardwoods hemicellulose is the O-acetyl4-O-methylglucuronoxylan (Hutterer et al., 2016).

Increment in pulp yield is a major goal of a chemical process, since it allows increased mill throughput and reduced specific wood consumption. For this purpose, the main approaches to meet such goal are: retarding or avoiding the carbohydrate degradation reactions, increasing delignification rate, and enhancing the mass transfer phenomenon during cooking (Colodette and Gomes, 20I4). In this context, lowering the residual effective alkali (REA) at end of cook appears as an interesting alternative to enhance kraft pulping performance, since allows a higher pulp yield by xylan precipitation onto the fibers (Goyal, 2017; Pinto et al., 2005). Currently the REA varies between 4- $18 \mathrm{~g} \cdot \mathrm{L}^{-1}$ for various mills. However, the range of $7-9 \mathrm{~g} \cdot \mathrm{L}^{-1}$ is more common. For some mills the REA target can be lowered without affecting the operation of evaporator and the recovery boiler (Goyal, 20I7).

Kraft cooking at low-REA presents certain economic advantages because the low EA demand implies less causticizing load, thus decreasing costs in the recovery cycle (Goyal, 20I7; Hansson and Hartler 1969; Hanna et al.1998). On the other hand, there are some drawbacks. Cooking at low-REA demands higher $\mathrm{H}$-factors, which can be provided by either increasing the cooking reaction time or the temperature. However, the increase in temperature results in larger steam consumption and therefore is economically disadvantageous (Nesselrodt, et. al., 20I5).
Another issue related to low-REA cooking is the potential risk of lignin precipitation, which may have considerable consequences in the bleaching costs and in the pulps bleachability as well as in the black liquor management due its increased viscosity with consequent system (Goyal, 2017; Hansson and Hartler 1969; Hanna et al.1998). However, Goyal (2017) showed that the cooking with low-REA did not show any appreciable difference of bleachability of the pulps, between pulps cooked with low-REA compared to high-REA pulps, and always results in higher pulp yield at a given delignification degree. Based on these results, a range of REA is recommended no loss on bleaching and with satisfactory pulp yield. Therefore, when considering low-REA cook one must balance the benefits and drawbacks.

Another important aspect linked to the increment in pulp yield is the kappa number itself. A very old cooking rule states that terminating a cook at high kappa number results in high pulp yield (Segura et al., 2016; MacLeod, 2007). Although this rule is very true when comparing total pulping yields, it is not so reliable for comparing to screened yields. Yield comparisons at different kappa numbers are usually not fair unless the results are compared at fixed REA and only lignin and HexA-free screen yield (Lignin HexA- free screen yield) be considered. Fair cooking yield comparison shall be done with the screened yield and not total yield because rejects are not fibers and they are usually discarded or very poorly reused in subsequent pulping cycles. In addition, if bleached pulp grades are sought after, one must compare the screen yields discounting their contents of lignin and HexA, the so-called lignin and HexA-free screened yield. This is necessary because during bleaching both lignin and HexA are largely removed and their weight shall not be accounted for in the yield measurements.

Besides, it is of paramount importance that cooking results be compared at similar REA, otherwise the yield results are meaningless (Colodette and Gomes, 2014). The only way to meet these constraints is by playing with both effective alkali charge and cooking time-temperature ( $\mathrm{H}$-factor) so that at the end of the cook, different kappa numbers are achieved at similar REA. This is exactly what was done in this study and it is a novelty in relation to previous studies.

In addition, wood type can also substantially affect pulp yield, as well as quality of the brown pulp, because Eucalyptus wood-fiber characteristics may vary substantially among the various species and clones as well as with age (Magaton et al., 2009). Thus, the pulping can affect in different way its composition, like as residual lignin nature, pulp carbohydrate composition, and the contents of alkali-leachable lignin and HexA present in hardwood kraft pulps (Colodette, 2002). Therefore, in this study was used four different types of Eucalyptus 
wood, typically used in pulp manufacture, for the greater reliability of the results obtained.

In this context, the objective of this study was to evaluate the impact of low and high residual effective alkali (I-2 and 8-9 g. $\mathrm{L}^{-1} \mathrm{NaOH}$ ), and pulp degree of delignification (kappa number 14-26) on the performance of kraft cooking Eucalyptus woods typically used in pulp manufacture.

\section{MATERIAL AND METHODS}

The feedstock consisted of wood chips from $E$. urophylla $\times E$. grandis hybrid, seven year old, grown in Brazil, and wood chips from E. nitens and E. globulus, sixteen years old, $E$ nitens $\times E$. globulus hybrid, twelve years old, all grown in Chile. The chips were classified according and air-dried conditioned SCAN-CN 40:94 standard procedure, dried to about $15 \%$ moisture, and stored for further use. A fraction of the air-dried accepts were used to evaluate the wood chemical composition. The chips were converted into sawdust in a knifemill (Willey Co, USA), classified according to TAPPI T257cm-85 standard and air-dried to $\sim 10 \%$ moisture.

The chemical composition was carried out on extractive-free wood sawdust (T280 pm-99). The content of acid-soluble lignin (Goldschmid, 197I), acidinsoluble lignin (T222 om-98), lignin syringyl/guaiacyl ratio (Lin and Dence, 1992), ash content (Tappi 211 om-93), sugars content (Wallis et al., 1996), total uronic acid (Scott 1979) and acetyl groups (Solár et al., 1987) were quantified. The wood basic density was measured according to SCAN-CM46:92 standard procedures.

The kraft cooking of the four Eucalyptus woods was performed in duplicate in a 7-L MK digester with $500 \mathrm{~g}$ of chips, oven dry (od) equivalent. The cooks were carried out with a liquor/wood ratio of $4 \mathrm{~L}: 1 \mathrm{~kg}, 30 \%$ sulfidity, maximum temperature of $165^{\circ} \mathrm{C}, 70$-min time-to-temperature and variable effective alkali charge and time-at-temperature to meet the kappa number targets of $14 \pm$ I, I $8 \pm I, 22 \pm$ I and 26 $\pm \mathrm{I}$ and the low $\left(\mathrm{I}-2 \mathrm{~g}^{-1} \mathrm{NaOH}\right)$ and high (8-9 $g \cdot L^{-1} \mathrm{NaOH}$ ) residual effective alkali (REA) for the various woods. By varying the time at the maximum temperature of $165{ }^{\circ} \mathrm{C}$ ( $\mathrm{H}$-factor) and the EA charge applied, using the trial-and-error technique, it was possible to meet the desired REA ranges at given kappa numbers. At the end of each cook, the chips were discharged and disintegrated in a 20-L hydrapulper at $2 \%$ consistency, washed and screened in an equipment (Voith Co., Germany) garnished with a flat screened of $0.2 \mathrm{~mm}$ slots, and at the end of this stage the rejects were collected. The screened pulps were analyzed for extractives content (TAPPI T280 pm-99), ash content (TAPPI T-2 I I om-93), kappa number (TAPPI T236 cm-85), HexA content (TAPPI T282 pm-07), viscosity (SCAN-CM I5:99), pentosans (TAPPI T280 om-99), sugar composition (SCAN- CM 7I:09) and brightness (ISO 2470). From the values of kappa number and HexA, the corrected kappa number values (only lignin) were determined according to the procedure described by Li and Gellerstedst (1997). The black liquor was analyzed for residual effective alkali (SCAN-N 33:94).

\section{RESULTS}

\section{Basic density and chemical composition of wood}

Basic density and chemical composition of the various Eucalyptus woods investigated in this study are presented in Table I.

Kraft pulping

Impact of REA, kappa number and wood type on EA charge and $\mathrm{H}$-factor requirements

The values of $\mathrm{H}$-factor and EA charge required to achieve kappa numbers of 14-26, with low-REA and high-REA, for the four wood types are show in Figure I.

TABLE IBasic density and chemical composition of Eucalyptus wood.

\begin{tabular}{|c|c|c|c|c|}
\hline Wood trait & $\begin{array}{l}\text { E. nitens } \mathrm{x} \\
\text { E. globulus } \\
\text { hybrid }\end{array}$ & E. nitens & E. globulus & $\begin{array}{c}\text { E. urophylla } x \\
\text { E. grandis } \\
\text { hybrid }\end{array}$ \\
\hline $\begin{array}{l}\text { Basic density } \\
\quad\left(\mathrm{kg} \cdot \mathrm{m}^{-3)}\right.\end{array}$ & 493 & 521 & 562 & 452 \\
\hline $\begin{array}{l}\text { Ash, } \\
(\%)\end{array}$ & 0.31 & 0.21 & 0.31 & 0.26 \\
\hline $\begin{array}{l}\text { Extractives in acetone } \\
\qquad(\%)\end{array}$ & 1.9 & 1.5 & 2.2 & 1.3 \\
\hline $\begin{array}{c}\text { Acid-insoluble lignin } \\
(\%)\end{array}$ & 20.6 & 20.7 & 19.5 & 24.0 \\
\hline $\begin{array}{c}\text { Acid-soluble lignin } \\
(\%)\end{array}$ & 5.6 & 5.0 & 5.2 & 4.1 \\
\hline $\begin{array}{l}\text { Total lignin } \\
(\%)\end{array}$ & 26.2 & 25.7 & 24.7 & 28.1 \\
\hline Lignin S/G ratio & 4.7 & 3.4 & 4.8 & 2.9 \\
\hline $\begin{array}{c}\text { Acetyl Groups } \\
(\%)\end{array}$ & 2.5 & 2.3 & 2.3 & 2.1 \\
\hline $\begin{array}{c}\text { Total uronic acids } \\
(\%)\end{array}$ & 2.7 & 3.1 & 2.5 & 2.8 \\
\hline $\begin{array}{c}\text { Glucans } \\
(\%)\end{array}$ & 48 & 49 & 52.0 & 52.1 \\
\hline $\begin{array}{l}\text { Xylans } \\
(\%)\end{array}$ & 16.2 & 16.7 & 14.2 & 11.6 \\
\hline $\begin{array}{l}\text { Galactans } \\
\text { (\%) }\end{array}$ & 0.9 & 0.9 & 1.4 & 1.3 \\
\hline $\begin{array}{l}\text { Mannans } \\
(\%)\end{array}$ & 1.2 & 1.4 & 1.0 & 0.8 \\
\hline $\begin{array}{l}\text { Arabinans, } \\
\text { (\%) }\end{array}$ & 0.3 & 0.2 & 0.3 & 0.2 \\
\hline $\begin{array}{l}\text { Total Sugar } \\
\text { (\%) }\end{array}$ & 66.6 & 68.2 & 68.9 & 66 \\
\hline $\begin{array}{l}\text { Cellulose }{ }^{a} \\
(\%)\end{array}$ & 46.8 & 47.6 & 51.0 & 51.3 \\
\hline $\begin{array}{l}\text { Hemicelluloses } \\
\text { (\%) }\end{array}$ & 25.0 & 26.0 & 22.7 & 19.6 \\
\hline
\end{tabular}

Cellulose $^{\mathrm{a}}=$ total glucans - glucans from glucomannans $(\mathrm{I} / \mathrm{I})$; hemicelluloses ${ }^{\mathrm{b}}=$ xylans + mannans + galactans + arabinans $+2 x$ glucans from glucomannans $)+$ uronic acids + acetyl groups. 


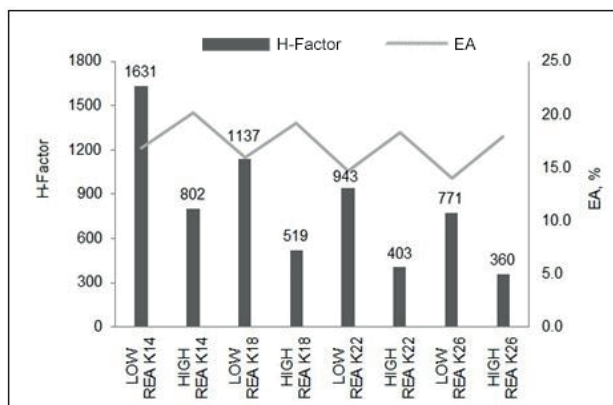

(A) E.nitens x E. Globulus hybrid

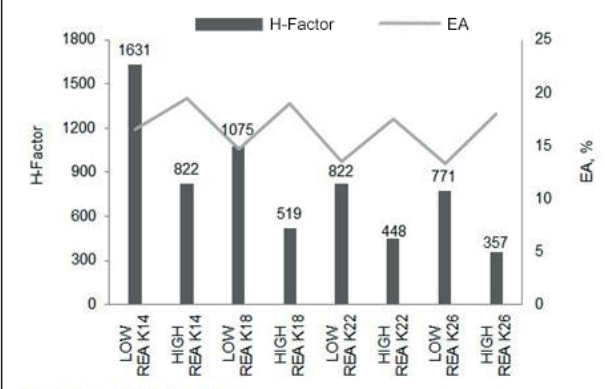

(C) E. Globulus

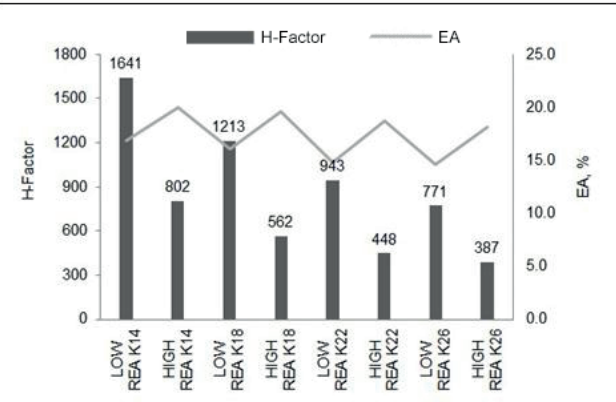

(B) E.nitens

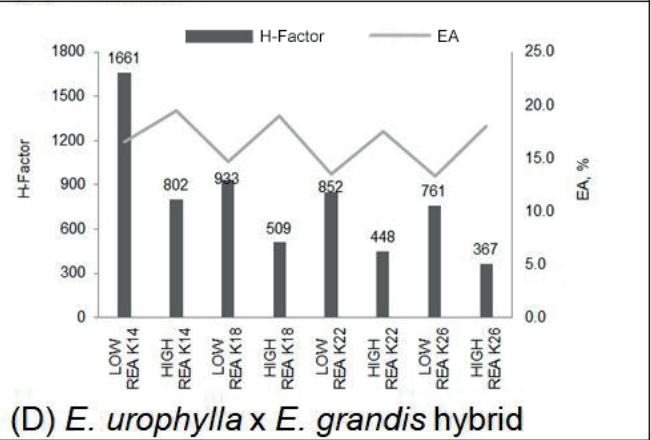

FIGURE I Effect of low and high residual effective alkali and kappa number variations on effective alkali charge and $\mathrm{H}$ factor requirements in kraft pulping of four Eucalyptus woods.

Impact of REA, kappa number and wood type on lignin-HexA free pulp screen yield

By considering pulps of different kappa numbers and similar REA, it was possible to investigate the impact of kappa number on lignin-HexA free screen yield and establish why different kappa numbers produce different yields (Table 2).

Impact of REA, kappa number and wood type on brown pulp chemical and physical compositions

The brown pulp chemical and physical characteristics are reported in Figure 2, Figure 3 and Table 3. The brown pulp xylan content refer to the xylan backbone only.

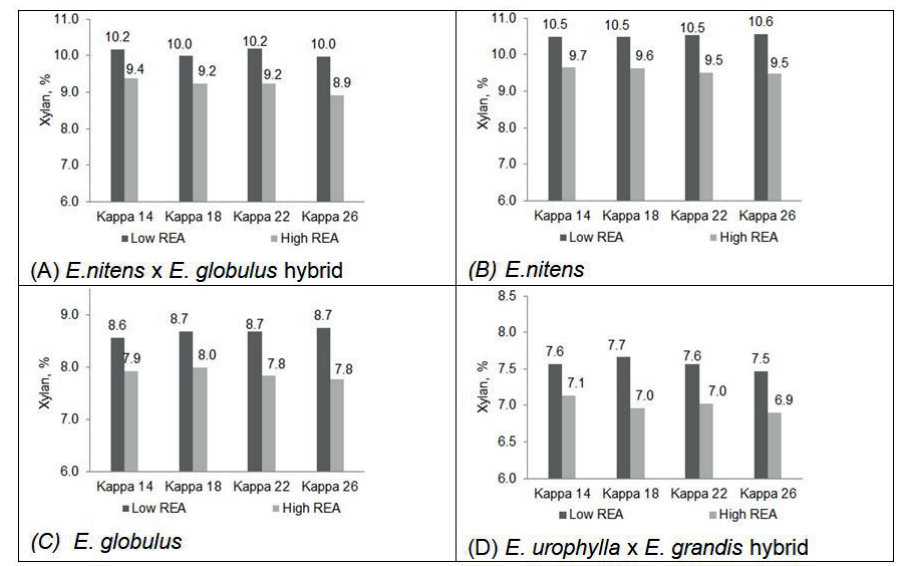

FIGURE 2 Effect of low and high REA and kappa number variations on pulp xylan backbone contents in kraft pulping of four Eucalypt woods.

\section{DISCUSSION}

Wood density and chemical composition

Basic densities were very different among the samples. The highest and lowest measured densities were for $E$. globulus $\left(562 \mathrm{~kg} \cdot \mathrm{m}^{-3}\right)$ and $E$. urophylla $\times E$. grandis hybrid $\left(452 \mathrm{~kg} \cdot \mathrm{m}^{-3}\right)$, respectively. These density values are typical of Eucalyptus woods used in pulp manufacture in South America (Gomide et al, 2005). The acetone extractive contents varied in the range of 1.3-2.2\%, with maximum and minimum values for $E$. globulus and $E$. urophylla $\times E$. grandis hybrid, respectively. In general, these levels of extractives may be considered low compared to other tropical hardwoods (Gomide et 
TABLE 2 Effect of kappa number on screened yield and lignin HexA-free yields in low-REA and high-REA kraft pulping of four Eucalypt woods.

\begin{tabular}{|c|c|c|c|c|c|c|c|c|}
\hline \multicolumn{9}{|c|}{ Parameter and Results } \\
\hline \multicolumn{9}{|c|}{ E. nitens $\times E$. globulus hybrid } \\
\hline Kappa Number & \multicolumn{2}{|c|}{14} & \multicolumn{2}{|c|}{18} & \multicolumn{2}{|c|}{22} & \multicolumn{2}{|c|}{26} \\
\hline $\operatorname{REA}\left(g \cdot L^{-1}\right)$ & I.0 & 8.2 & 1.2 & 8.1 & 1.0 & 8.3 & I.I & 8.0 \\
\hline Black liquor $(\mathrm{pH})$ & 12.1 & 12.8 & 12.1 & 12.7 & 12.2 & 12.8 & 12.1 & 12.8 \\
\hline Screen yield (\%) & 51.7 & 50.8 & 52.7 & 51.6 & 53.1 & 51.7 & 53.1 & 51.1 \\
\hline aLig-HexA Free Screen Yield (\%) & 50.3 & 49.4 & 50.9 & 49.9 & 51.0 & 49.7 & 50.6 & 48.8 \\
\hline Reject (\%) & 0.0 & 0.2 & 1.3 & 1.2 & 2.6 & 3.0 & 4.0 & 4.5 \\
\hline${ }^{\mathrm{b}} \Delta$ due to decrease REA & 0.9 & 1.0 & 1.3 & 1.8 & & & & \\
\hline \multicolumn{9}{|c|}{ E. nitens } \\
\hline Kappa Number & \multicolumn{2}{|c|}{14} & \multicolumn{2}{|c|}{18} & \multicolumn{2}{|c|}{22} & \multicolumn{2}{|c|}{26} \\
\hline $\operatorname{REA}\left(g \cdot L^{-1}\right)$ & 1.3 & 8.0 & 1.0 & 8.9 & 1.0 & 9.0 & 1.0 & 8.4 \\
\hline Black liquor $(\mathrm{pH})$ & 12.1 & 12.7 & 12.1 & 12.8 & 12.2 & 12.8 & 12.2 & 12.8 \\
\hline Screen yield, \% & 52.2 & 51.4 & 54.1 & 53.0 & 54.9 & 53.5 & 54.6 & 52.8 \\
\hline a Lig-HexA Free Screen Yield (\%) & 50.9 & 50.0 & 52.4 & 51.3 & 52.8 & 51.4 & 52.1 & 50.4 \\
\hline Reject $(\%)$ & 0.1 & 0.3 & 0.3 & 0.4 & I.I & I.I & 2.8 & 3.0 \\
\hline${ }^{\mathrm{b}} \Delta$ due to decrease REA & 0.9 & I.I & 1.4 & 1.7 & & & & \\
\hline \multicolumn{9}{|c|}{ E. globulus } \\
\hline Kappa Number & \multicolumn{2}{|c|}{14} & \multicolumn{2}{|c|}{18} & \multicolumn{2}{|c|}{22} & \multicolumn{2}{|c|}{26} \\
\hline $\operatorname{REA}\left(g \cdot L^{-1}\right)$ & 1.3 & 8.2 & 1.2 & 8.1 & 1.0 & 8.5 & 1.0 & 8.7 \\
\hline Black liquor $(\mathrm{pH})$ & 12.2 & 12.7 & 12.1 & 12.7 & 12.1 & 12.8 & 12.1 & 12.8 \\
\hline Screen yield (\%) & 53.9 & 53.0 & 54.8 & 53.7 & 55.1 & 53.7 & 54.9 & 53.2 \\
\hline aLig-HexA Free Screen Yield (\%) & 52.4 & 51.6 & 52.9 & 51.9 & 52.9 & 51.6 & 52.3 & 50.7 \\
\hline Reject (\%) & 0.1 & 0.3 & 1.5 & 1.2 & 3.0 & 3.2 & 3.8 & 4.4 \\
\hline${ }^{\mathrm{b}} \triangle$ due to decreased REA & 0.9 & 1.0 & 1.3 & 1.6 & & & & \\
\hline \multicolumn{9}{|c|}{ E. urophylla $\mathrm{x}$ grandis hybrid } \\
\hline Kappa Number & \multicolumn{2}{|c|}{14} & \multicolumn{2}{|c|}{18} & \multicolumn{2}{|c|}{22} & \multicolumn{2}{|c|}{26} \\
\hline $\operatorname{REA}\left(g \cdot \mathrm{L}^{-1}\right)$ & 2.0 & 9.0 & 1.8 & 9.0 & 1.0 & 8.3 & I.I & 9.0 \\
\hline Black liquor $(\mathrm{pH})$ & 12.1 & 12.8 & 12.1 & 12.7 & 12.1 & 12.7 & 12.1 & 12.8 \\
\hline Screen yield (\%) & 52.5 & 52.0 & 53.7 & 52.7 & 54.3 & 52.9 & 54.3 & 52.4 \\
\hline aLig-HexA Free Screen Yield (\%) & 51.1 & 50.6 & 51.9 & 51.0 & 52.2 & 50.8 & 51.8 & 50.0 \\
\hline Reject (\%) & 0.0 & 0.2 & 0.4 & 0.6 & 1.2 & 1.5 & 2.1 & 2.3 \\
\hline${ }^{\mathrm{b}} \Delta$ due to decreased REA & 0.5 & 0.9 & 1.3 & 1.8 & & & & \\
\hline
\end{tabular}

${ }^{\mathrm{a}}$ Lignin-HexA Free Screen Yield = Screen yield - (lignin yield + HexA yield). ${ }^{\mathrm{b}} \Delta$ Lignin-HexA Free Screen Yield due to decrease REA..

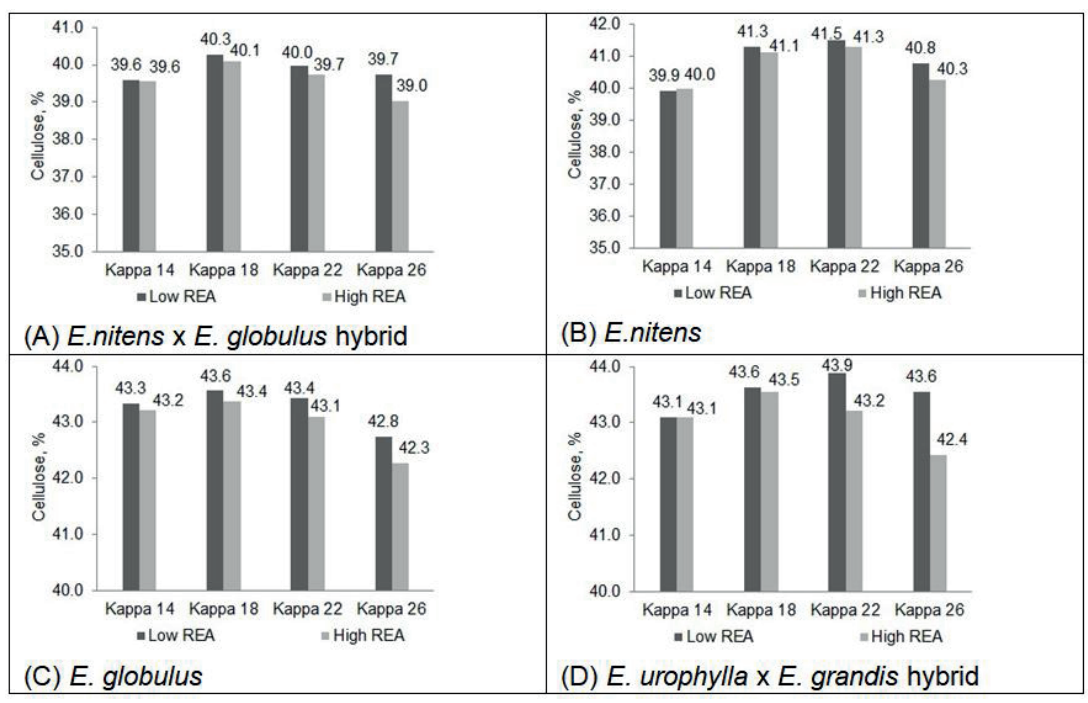

FIGURE 3 Effect of low and high REA and kappa number variations on pulp cellulose contents in kraft pulping of four eucalypt woods. 
TABLE 3 Contents of lignin, HexA and MeGlcA and physical characteristic of unbleached pulps, viscosity and brightness, derived from cooks to kappa numbers of 14-26 at low-REA and high-REA of four Eucalyptus wood species.

\begin{tabular}{|c|c|c|c|c|c|c|c|c|}
\hline \multicolumn{9}{|c|}{ Parameter and Results } \\
\hline \multicolumn{9}{|c|}{ E. nitens $x$ E. globulus hybrid } \\
\hline Kappa Number & \multicolumn{2}{|c|}{14} & \multicolumn{2}{|c|}{18} & \multicolumn{2}{|c|}{22} & \multicolumn{2}{|c|}{26} \\
\hline Residual Effective Alkali $\left(\mathrm{g} \cdot \mathrm{L}^{-1}\right)$ & 1.0 & 8.2 & 1.2 & 8.1 & 1.0 & 8.3 & I.I & 8.0 \\
\hline aLignin content (\%) & 1.2 & $\mathrm{I} .3$ & 2.0 & 1.9 & 2.7 & 2.6 & 3.4 & 3.2 \\
\hline HexA content $\left(\mathrm{mmol} \cdot \mathrm{kg}^{-1}\right)$ & 63 & 68 & 58 & 62 & 49 & 57 & 41 & 54 \\
\hline MeGlcA (\%) & I.I & 0.9 & 1.3 & $\mathrm{I} . \mathrm{I}$ & 1.6 & 1.4 & 1.9 & 1.6 \\
\hline Viscosity $\left(\mathrm{dm}^{3} \cdot \mathrm{kg}^{-1}\right)$ & 1059 & 990 & 1189 & 1096 & 1280 & 1181 & 1389 & 1270 \\
\hline Brightness (\%ISO) & 33.0 & 35.6 & 30.4 & 34.1 & 29.2 & 32.9 & 28.4 & 32 \\
\hline \multicolumn{9}{|c|}{ E. nitens } \\
\hline Kappa Number & \multicolumn{2}{|c|}{14} & \multicolumn{2}{|c|}{18} & \multicolumn{2}{|c|}{22} & \multicolumn{2}{|c|}{26} \\
\hline Residual Effective Alkali $\left(\mathrm{g} \cdot \mathrm{L}^{-1}\right)$ & 1.3 & 8.0 & 1.0 & 8.9 & 1.0 & 9.0 & 1.0 & 8.4 \\
\hline aLignin content (\%) & 1.3 & 1.2 & 2.0 & 1.9 & 2,7 & 2.6 & 3.3 & 3.2 \\
\hline HexA content $\left(\mathrm{mmol} \cdot \mathrm{kg}^{-1}\right)$ & 61 & 67 & 57 & 60 & 50 & 55 & 46 & 53 \\
\hline MeGlcA (\%) & 1.0 & 0.8 & 1.2 & 1.0 & 1.4 & 1.2 & 1.6 & $\mathrm{I} .3$ \\
\hline Viscosity $\left(\mathrm{dm}^{3} \cdot \mathrm{kg}^{-1}\right)$ & 1035 & 967 & 1191 & 1100 & 1292 & 1176 & 1400 & 1280 \\
\hline Brightness (\%ISO) & 33.4 & 37.8 & 31.3 & 36.2 & 30.4 & 34.8 & 29.9 & 34.3 \\
\hline \multicolumn{9}{|c|}{ E. globulus } \\
\hline Kappa Number & \multicolumn{2}{|c|}{14} & \multicolumn{2}{|c|}{18} & \multicolumn{2}{|c|}{22} & \multicolumn{2}{|c|}{26} \\
\hline Residual Effective Alkali $\left(\mathrm{g} \cdot \mathrm{L}^{-1}\right)$ & 1.3 & 8.2 & 1.2 & 8.1 & 1.0 & 8.5 & 1.0 & 8.7 \\
\hline aLignin content (\%) & $\mathrm{I} .4$ & 1.3 & 2.0 & 1.9 & 2.7 & 2.6 & 3.4 & 3.2 \\
\hline HexA content $\left(\mathrm{mmol} \cdot \mathrm{kg}^{-1}\right)$ & 54 & 58 & 51 & 55 & 45 & 53 & 40 & 51 \\
\hline MeGlcA (\%) & I.I & 0.9 & 1.3 & 1.0 & 1.5 & 1.2 & 1.6 & 1.4 \\
\hline Viscosity $\left(\mathrm{dm}^{3} \cdot \mathrm{kg}^{-1}\right)$ & 1090 & 1034 & 1184 & 1110 & 1309 & 1190 & 1425 & 1277 \\
\hline Brightness (\%ISO) & 29.3 & 31.9 & 28.0 & 31.4 & 26.7 & 28.5 & 24.8 & 27.7 \\
\hline \multicolumn{9}{|c|}{ E. urophylla $x$ grandis hybrid } \\
\hline Kappa Number & \multicolumn{2}{|c|}{14} & \multicolumn{2}{|c|}{18} & \multicolumn{2}{|c|}{22} & \multicolumn{2}{|c|}{26} \\
\hline Residual Effective Alkali $\left(\mathrm{g} \cdot \mathrm{L}^{-1}\right)$ & 2.0 & 9.0 & 1.8 & 9.0 & 1.0 & 8.3 & I.I & 9.0 \\
\hline aLignin content (\%) & 1.3 & I.I & 1.9 & 1.8 & 2.6 & 2.5 & 3.4 & 3.1 \\
\hline HexA content $\left(\mathrm{mmol} \cdot \mathrm{kg}^{-1}\right)$ & 66 & 74 & 63 & 66 & 55 & 66 & 41 & 63 \\
\hline MeGlcA (\%) & 0.9 & 0.8 & 1.2 & 1.0 & 1.4 & 1.2 & 1.6 & 1.4 \\
\hline Viscosity $\left(\mathrm{dm}^{3} \cdot \mathrm{kg}^{-1}\right)$ & 1009 & 963 & 1180 & 1130 & 1311 & 1240 & 1400 & 1330 \\
\hline Brightness (\%ISO) & 34.8 & 37.4 & 32.9 & 36.8 & 31.2 & 35.7 & 29.9 & 34.2 \\
\hline
\end{tabular}

aLignin content $=0.15 \times(\mathrm{k}-0.086 \times \mathrm{CHexA})$, where $\mathrm{k}$ is the kappa number, and CHexA is HexA content in $\mathrm{mmol}^{\mathrm{k}} \mathrm{kg}^{-1}(\mathrm{Li} \& \mathrm{Gellerstedt}, 1997)$

al, 2005). The ash content, which corresponds to the wood inorganic materials, was similar for $E$. nitens $x E$. globulus hybrid, E. globulus and $E$. urophylla $\times E$. grandis hybrid, with value of $0.3 \%$, while for $E$. nitens, the ash content was slightly smaller, with value of $0.2 \%$. Total carbohydrate content ranged from $66 \%$ to $69 \%$, with glucan and xylan as the major components. There were slight variations in the contents of arabinans, galactans and mannans among the various wood species but overall the contents of these sugars were irrelevant, which is positive given their low stability throughout kraft cooking. Glucans content varied in the range of $48-52 \%$ with the higher values for $E$. globulus and the hybrid of $E$. grandis $x E$. urophylla. The xylan contents varied in the range of I I.6-16.7\% with higher values for $E$. nitens and the hybrid of $E$. globulus $\times E$. nitens. Similar trends have been reported elsewhere (Magaton et al., 2006; Pinto et al., 2005). Total wood lignin content varied from $24 \%$ to
$28 \%$ with the lowest value for $E$. globulus and the highest for $E$. urophylla $\times E$. grandis hybrid. The lower content of lignin in $E$. globulus compared to others wood has been reported elsewhere (Santos et al., 2012; Pinto et al., 2005; Rencoret et al., 2007; Magaton et al., 2006). The low wood lignin content is quite favorable for bleached pulp production because it reduces wood and chemical demand, which are the most relevant production costs components (Gomide 2005; Pinto et al., 2005; Rencoret et al., 2007). The wood contents of acetyl (2.l-2.5\%) and uronic acid (2.5-3.1\%) groups were in the range of values reported elsewhere (Magaton et al., 2009). More acetyl groups were found in the woods containing more xylans as should have been expected. However, this trend was not observed for the uronic acids. In fact, the E. urophylla $\times$ E. grandis hybrid wood, which contained only $11.6 \%$ xylans, presented $2.8 \%$ of uronic acid groups, while the $E$. nitens $\times E$. globulus hybrid had $16.2 \%$ 
xylans and only $2.7 \%$ uronic acids. The cellulose (46.8$51.3 \%)$ and hemicelluloses $(19.6-26 \%)$ contents were very different among the various wood samples. The highest and lowest cellulose contents were measured for E. urophylla $\times E$. grandis hybrid $(5 \mathrm{I} .3 \%)$ and $E$. nitens $\times E$. globulus hybrid (46.8\%), respectively. For hemicelluloses content, the highest and lowest values were measured for $E$. nitens $(26 \%)$ and $E$. urophylla $\times E$. grandis hybrid (19.6\%), respectively.

Kraft pulping

Impact of REA, kappa number and wood type on EA charge and $\mathrm{H}$-factor requirements

It is observed that the EA charge and $\mathrm{H}$-factor were largely influenced by the target REA, with higher $\mathrm{H}$-factors and low EA charge requirements for the low-REA cooks and the opposite for the high-REA cooks. Kraft cooking at lowREA presents certain economic advantages because the low EA demand implies less causticizing load, thus decreasing costs in the recovery cycle. In addition, cooking with low EA tend to preserve carbohydrates during cooking with potential yield and pulp viscosity gains (Pinto et. al., 2005). On the other hand, cooking at low-REA demands higher $\mathrm{H}$-factors, which can be provided by either increasing the cooking reaction time or the temperature. In a mill scale, the natural choice would be increasing the temperature because the increase in reaction time would decrease mill throughput. The increase in temperature results in larger steam consumption and therefore is economically disadvantageous. Therefore, when considering low-REA cook one must balance the cost savings due to reduced causticizing load against the increase in steam consumption or the increase in reaction time (Nesselrodt, et. al., 2015). This is a difficult calculation to be mendeadly when we consider the different needs of mills. For some mills the REA target can be lowered without affecting the cost the operation of evaporation, the recovery boiler and mill throughput. For example, for some mills, the lower white liquor requirement, hence, an energy savings in lime kiln, is a positive factor if recovery boiler limited. This can permit the increase in reaction time can be possible without change about costs.

In average, considering all four woods, the lowREA cooks required about $20 \%$ less effective alkali to achieve the target kappa in relation to the high-REA cooks. For example, for the $E$. urophylla $\times E$. grandis hybrid wood, the low-REA cooks allowed for EA charge savings of 26 and $15 \%$ for kappa numbers 26 and 14 , respectively, in relation to the high-REA cooks. However,
low-REA cooks demanded, in average, about $50 \%$ more $\mathrm{H}$-factor in relation to the high-REA cooks, considering all four Eucalyptus woods and kappa number values. The maximum and minimum $\mathrm{H}$-factor increases due to low-REA cooks were $57 \%$ and $45 \%$ for $E$. nitens $\times E$. globulus hybrid cooked at kappa 22 and I8, respectively. In addition, in the kappa number range investigated, 14-26, the EA charge and $\mathrm{H}$-factor requirements tend to decrease as the reduction of delignification degree. No significant effect of wood type was observed on EA charge and $\mathrm{H}$-factor requirements for a given REA and kappa number value.

Impact of REA, kappa number and wood type on lignin-HexA free pulp screen yield

In order to compare pulping screed yield at different kappa numbers, the REA at the end of the cooks must be similar and only lignin and HexA-free screen yield must be considered. The only way to meet these constraints is by playing with both effective alkali charge and cooking time-temperature ( $\mathrm{H}$-factor) so that at the end of the cook, different kappa numbers are achieved at similar REA. This is exactly what was done in this study.

Various studies have indicated that higher brown pulp screen yields are obtained when cooking is terminated at higher kappa numbers (Segura et al., 2016; Colodette and Gomes, 2014; Colodette et al., 2007). This trend was also found in our study, except for kappa number 26, due to high reject content, as can be seen in Table 2. However, if one considers the lignin-and HexA-free screen yield (bleached yield), this trend is not so clear. The results presented in Table 2 show that the lignin-HexA free screen yield tend to remain similar with increasing kappa number, regardless of raw material and REA, except for the kappa number 14 pulp that showed lower yields in relation to those of kappa 18-26 pulps. For example, for $E$. urophylla $\times E$. grandis hybrid cooked at low-REA, the lignin- and HexA-free yields were of $51.1,51.9,52.2$ and $51.8 \%$ for kappa numbers of 14,18 , 22 and 26, respectively. Thus, the removal of lignin is the main cause of yield decrease in the kappa range of 18-26. For the kappa number 26 , the reject content increased in relation to other kappa numbers, this is explaining the decreasing of the yield.

According to Santiago (2008), a decreasing in the effective alkali charge leads to increased pulping yield and selectivity thereof. This behavior was notable in this paper, since an increase maximum of $1.8 \%$ in the ligninand HexA-free pulp screen yield was achieved at kappa number 26 for the low-REA cook, for both hybrids of $E$. 
nitens $\times$ E. globulus and $E$. urophylla $\times E$. grandis woods. For kappa number 18, more commonly required by mill, a smaller yield gains were achieved in the order of $1.0 \%$ for $E$. nitens $\times E$. globulus hybrid, I.I\% for $E$. nitens, $1.0 \%$ for $E$. globulus and $0.9 \%$ for $E$. urophylla $x$ E. grandis hybrid (Table 2). The cooking with low residual effective alkali results higher yield, likely due to improved preservation of hemicelluloses and/or partial precipitation of dissolved xylans onto the fibers (Santiago and Neto, 2008; Colodette, et al., 2002).

As the pulping conditions, among woods, were very similar for a fixed kappa number, yield comparisons among the various woods is fair and possible. The maximum values of lignin-HexA free screen yields were 52.9, 52.8, 52.2 and $51.0 \%$ from $E$. globulus (kappa number 18), E. nitens, E. urophylla $\mathrm{x}$ grandis hybrid, E. nitens $\times$ E. globulus hybrid (kappa number 22 ), respectively. It is worth noting that at the highREA the same yield trends among the various woods was observed, except the absolute yield values were in general lower. E. globulus gave the highest yields and the $E$. globulus $x E$. nitens hybrid the lowest. The relative content of lignin in wood certainly contribute to different pulping performances of different Eucalyptus species, and, the differences observed between $E$. globulus and $E$. nitens $\times E$. globulus hybrid are clearly related to this factor (Table I). Also, it is worth noting that, despite there is the potential risk of lignin precipitation at low-REA cooking, that did not occur in this study, since the black liquor $\mathrm{pH}$ was about 12.2. According to Gomes (200I), at normal cooking conditions, the lignin precipitation occurs in $\mathrm{pH}$ lower that 12 , being considerable in $\mathrm{pH}$ 9.5 In addition, the low-REA cooks can positively impact on other black liquor properties, with energy savings in black liquor evaporation due to high ratio organic to inorganic present in black liquor (Goyal, 2017; Hanna, 1998; Hanson and Hartler, 1969).

Impact of REA, kappa number and wood type on brown pulp chemical and physical compositions

The two main components of brown pulps are cellulose and hemicelluloses, with lignin and HexA representing a very small fraction of the pulp on a weight basis. The xylans are synonym of hemicelluloses in Eucalyptus kraft pulp. The contents of xylan backbone in the original woods were 16.2, 16.7, 14.2 and II.6\% for $E$. nitens $\times E$. globulus hybrid, $E$. nitens, $E$. globulus and $E$. urophylla $\times E$. grandis hybrid, respectively (Table I). The xylan backbone contents in the brown pulps produced in different kappa numbers at low-REA and
high-REA, on wood weight, varied from 8.9-10.2, 9.510.6, 7.8-8.7, 6.9-7.7\% for E. nitens $\times$ E. globulus hybrid, $E$. nitens, $E$. globulus and $E$. urophylla $\times E$. grandis hybrid, respectively. Hence, it is clear that the xylans retained in the pulp correlates to the original xylan backbone content present in the wood. Significant amounts of the xylan backbone were lost across kraft cooking, with the effect being more significant for the high-REA cooks. The xylan backbone loss across pulping, for the various kappa numbers and wood types, represented from $3.9 \%$ to $6.2 \%$ (wood basis) for low-REA cooks and from $4.5 \%$ to $7.3 \%$ (wood basis) for the high-REA cooks. In the lowREA cooks, considering all four kappa values, the relative xylan losses were 38, 37, 39 and 35\%, respectively, for $E$. nitens $\times E$. globulus hybrid, $E$. nitens, $E$. globulus and E. urophylla $x E$. grandis hybrid. In the high-REA cooks, the relative xylan losses were about $5 \%$ higher being 43 , 43, 44 and $40 \%$, respectively, for $E$. nitens $\times E$. globulus hybrid, $E$. nitens, $E$. globulus and $E$. urophylla $\times E$. grandis hybrid. No significant effect of kappa number value was observed on xylan retention for a given REA value, regardless of wood type. For example, for the $E$. globulus wood cooked at low-REA, the increase of kappa number from 14 to 26 resulted xylan losses of $39 \%$, in both cases. Similar trends were observed for the other wood types. No effect on xylan removal in different kappa numbers, for the various Eucalyptus woods are explained by the REA, which was carefully kept constant. On the other hand, when the focus is to analyze the effect of REA, the low-REA cooks led to smaller xylans losses, suggesting that effective alkali charge play a key role in the stability and retention of this polysaccharide during the pulping process. Previous works concerning the impact low-REA cooks on carbohydrate dissolution of unbleached pulp have demonstrated significantly increased both total yield and viscosity, for similar kappa number, which was mainly attributed to higher carbohydrates retention, especially xylan (Santiago, 2008; Achrén et al., 1998).

The contents of cellulose in the original woods were 46.8, 47.6, 51.0 and $51.3 \%$ for $E$. nitens $\times E$. globulus hybrid, E. nitens, E. globulus and $E$. urophylla $\mathrm{x}$ E. grandis hybrid, respectively (Table I). The cellulose contents in the brown pulps produced in different kappa numbers at low-REA and high-REA, on wood weight, varied from 39.0-40.3, 39.9-4I.5, 42.3-43.6 and 42.4$43.9 \%$ for $E$. nitens $\times E$. globulus hybrid, $E$. nitens, $E$. globulus and $E$. urophylla $\times E$. grandis hybrid, respectively. Hence, it is clear that the cellulose retained in the pulp correlates to the original cellulose content present in the wood. A smaller amount of the cellulose was lost across 
kraft cooking when compared to loss of xylan backbone, with the effect being more significant for the high-REA cooks. The cellulose loss across pulping, for the various kappa numbers and wood types, represented from $6.7 \%$ to $7.8 \%$ (wood basis) for low-REA cooks and from $7.0 \%$ to $8.3 \%$ (wood basis) for the high-REA cooks. In the low-REA cooks, considering all four kappa values, the relative cellulose losses were 15.0, I4.I, I5.3 and I5.1\%, respectively, for $E$. nitens $x E$. globulus hybrid, $E$. nitens, $E$. globulus and $E$. urophylla $\times E$. grandis hybrid. In the high-REA cooks, the relative cellulose losses were in average $0.6 \%$ higher being 15.4 , 14.7 , 15.7 and $16.2 \%$, respectively, for $E$. nitens $x E$. globulus hybrid, $E$. nitens, $E$. globulus and $E$. urophylla $\times E$. grandis hybrid. No significant effect of kappa number value was observed on cellulose retention for a given REA value, regardless of wood type, except for kappa number 26. For example, for the $E$. globulus wood cooked at low-REA, the increase of kappa number from 14 to 26 resulted cellulose losses of I5.I and $16.1 \%$, respectively. Similar trends were observed for the other wood types. The no effect on cellulose removal in different kappa numbers, for the various Eucalyptus woods are explained by the fixed REA, which was carefully kept constant. Already the difference found for kappa number 26 can be explained due to higher amount of reject obtained in the cooking. On the other hand, when the focus is to analyze the effect of REA, the low-REA cooks led to smaller celluloses losses, suggesting that effective alkali charge play a key role in the stability and retention of this polysaccharide during the pulping process. The higher cellulose loss in the highREA cooks is explained by enhanced secondary peeling reactions in the presence of higher alkali concentration. In addition to xylans and cellulose, Eucalyptus brown pulp contains minor quantities of lignin, HexA and MeGlcA.

The lignin contents in the brown pulp produced in different kappa numbers and at low-REA and highREA was calculated according to $\mathrm{Li}$ \& Gellerstedt ( 1997). Higher amounts of the lignin were obtained for the low-REA cooks. The lignin content for the various kappa numbers and the four wood types, represented from $1.4 \%$ to $3.4 \%$ for low-REA cooks and from I.1\% to $3.1 \%$ for the high-REA cooks. As expected, the lignin content trends to increase as the kappa number increases in the range of 14-26. For example, for the $E$. globulus wood cooked at low-REA, the increase of kappa number from 14 to 26 resulted lignin content increase of I.4 to $3.4 \%$. Similar trends were observed for the other wood types. In general, no significant effect of wood type was observed on lignin content for a given REA and kappa number value, except to $E$. globulus that present the higher values of lignin, since HexA content was the smallest. The effect on lignin content at low and high cooks, for the various Eucalyptus woods and different kappa numbers are explained by lignin precipitation (Colodette, 2002). On the other hand, when the focus is to analyze the effect of kappa number and wood type on lignin content, there are clear trend that the increase of the kappa number lead to increases lignin content regardless of wood. However, the lignin content at kappa number fixed, to a given wood type, depends of HexA content formed during pulping (Magaton et al., 2008).

Higher amounts of the HexA were obtained for the high-REA cooks. The HexA content for the various kappa numbers and the four wood types, represented from 40 to $66 \mathrm{mmol} \cdot \mathrm{kg}^{-1}$ for low-REA cooks and from $5 \mathrm{I}$ to $74 \mathrm{mmol} \cdot \mathrm{kg}^{-1}$ for the high-REA cooks. In the kappa number range investigated, the HexA content increases as delignification proceeds. For example, for the $E$. globulus wood cooked at low-REA, the increase of kappa number from 14 to 26 resulted HexA decrease of 54 to $40 \mathrm{mmol}$. $\mathrm{kg}^{-1}$. Similar trends were observed for the other wood types. In general, no significant effect of wood type was observed on HexA content for a given REA and kappa number value, except to $E$. globulus that present the lower values of HexA. The smaller HexA content found in lowREA cooks in relation to high-REA cooks can be associated to decrease of the reactions rate HexA formation, since the EA charge is smaller to achieve target REA and the rate of formation/degradation of HexA was shown to depend essentially on HO- (Gomide 2005; Hutterer et al., 2017). On the other hand, HexA content in pulps increased along the kraft pulping process due to adjusted the pulping time to obtain a target kappa number, while keeping the other pulping parameters at partially constant levels (BergnorGidnert et al., 1998). The smaller amount of HexA in E. globulus in relation the others Eucalyptus species can be due to varying contents of 4-O-methyl- glucuronoxylans among species that influences the amount of HexA formed (Magaton et al., 2008).

The most of the uronic acids groups, present in hardwood, are 4-0-methylglycouronic acid group (MeGlcAs). Therefore, it was assumed in this study, that the uronic acid quantified in the pulp are all 4-0-methylglycouronic acid group (MeGlcA). Higher amounts of the MeGlcA were obtained for the lowREA cooks. The MeGlcA content for the various kappa numbers and the four wood types, represented from I. I to $1.9 \%$ for low-REA cooks and from 0.8 to $1.3 \%$ for the high-REA cooks. In the kappa number range investigated, 
as kappa number decreases, the MeGlcA also decreases. For example, for the $E$. globulus wood cooked at lowREA, the increase of kappa number from 14 to 26 resulted MeGlcA increase of 1.1 to $1.6 \%$. Similar trends were observed for the other wood types. In general, no significant effect of wood type was observed on MeGlcA content for a given REA and kappa number value, except to $E$. nitens $\times E$. globulus hybrid that presented values slightly higher to kappa numbers 22 and 26 . The higher MeGlcA content found in low-REA cooks in relation to high-REA cooks can be associated to smaller xylans losses and decreased formation rate of HexA, since the MeGlcA are the precursors of HexA (Gomes et al., 20I4; Magaton, 2008). On the other hand, MeGlcA content in pulps increased as the kappa number increases due to adjusted the pulping time (decreasing of $\mathrm{H}$-factor) to obtain a target kappa number, while keeping the other pulping parameters at partially constant levels (Monrroy et al., 2008). The higher amount of MeGlcA in $E$. nitens $\times E$. globulus hybrid in relation the others Eucalyptus species can be due to varying contents of 4-O-methyl-glucuranoxilanas among species that influences the remaining amount of MeGlcA in pulp (Magaton et al., 2008).

A clear tendency of viscosity improvement in pulps from low-REA cooks was observed, representing relative estimated viscosity gains of $93 \mathrm{dm}^{3} \cdot \mathrm{kg}^{-1}$ for $E$. nitens $\times$ E. globulus hybrid, $91 \mathrm{dm}^{3} \cdot \mathrm{kg}^{-1}$ for $E$. nitens, 74 $\mathrm{dm}^{3} \cdot \mathrm{kg}^{-1}$ for $E$. globulus and $50 \mathrm{dm}^{3} \cdot \mathrm{kg}^{-1}$ for $E$. urophylla $x E$. grandis hybrid in relation to pulps from high-REA cooks, when cooked to kappa number 18. The viscosity gains increase as the kappa number increases. For example, considering all four woods, the pulps cooked to kappa number 26 from low-REA cooks had the viscosity gains of about $120 \mathrm{dm}^{3} \cdot \mathrm{kg}^{-1}$. In the kappa number range investigated, 14-26, the viscosity loss increases as the kappa number decreases (delignification increases). For example, for the $E$. globulus wood cooked at low-REA, the decrease of kappa number from 26 to 14 resulted viscosity decrease of 1425 to $1090 \mathrm{dm}^{3} \cdot \mathrm{kg}^{-1}$. Similar trends were observed for the other wood types. In general, no significant effect of wood type was observed on viscosity for a given REA and kappa number value. The higher viscosity values found in pulps from lowREA cooks in relation to high-REA cooks is associated to higher preservation of cellulose due to possible decrease of alkaline hydrolysis reactions and consequently the secondary peeling reactions in the cellulose chains (Santiago, 2008; Santiago and Neto, 2008). On the other hand, viscosity in pulps decreased along the kraft pulping process due to higher degradation of the carbohydrate chains (Gomide et al., 20II). Similar viscosity values found among the four wood types, for a given REA and kappa number value, can be due to keeping the pulping parameters at partially constant levels.

A negative impact on pulp brightness was caused by the decrease of REA concentration in the pulping process. For example, for the E. globulus wood cooked in kappa number 18, the cooks at low-REA in relation to high-REA resulted brightness decrease of 31.4 to $28 \%$ ISO. As expected, in the kappa number range investigated, 14-26, the brightness increases as delignification proceeds. For example, the decrease of kappa number from 26 to 14 for the $E$. globulus wood cooked at low-REA, resulted brightness increase of 24.8 to $29.3 \%$ ISO. Similar trends were observed for the other wood types. Significant effects of wood type were observed on brightness for a given REA and kappa number value, manly for $E$. urophylla $\times E$. grandis hybrid ( $32.9 \%$ ISO) and E. globulus (28\% ISO) that present the higher and the smaller brightness, respectively, for brown pulps produced in kappa numbers 18 and at low-REA. The smaller brightness obtained in pulps from low-REA cooks in relation to high-REA cooks can be explained by the decrease in the content of aliphatic hydroxyl groups and the carboxyl groups in the residual lignin (Colodette et al., 2002). It was reported by Aurell and Hartler (1965) as well, that a low residual alkali concentration in the cook gives rise to pulps with a low brightness due to a formation of chromophoric structures in the lignin. Also, Hartler and Norrström (1969) demonstrated that applying a high $\mathrm{H}$-factor to reach a given kappa number is accompanied by a low residual amount of $\beta-O-4$ structures in the residual lignin. On the other hand, brightness in pulps decreased as the reduction of delignification degree due to higher amount of residual lignin in the pulp (Gustavsson, 2006). The different brightness values found among the wood types studied, to a given REA and kappa number value can be explained by HexA and lignin content that composing the kappa number (Costa and Colodette, 2007).

\section{CONCLUSIONS}

This study investigates the effect of residual effective alkali (low and high) and pulp degree of delignification (kappa 14-26) on the performance of kraft cooking of four Eucalyptus woods. Regardless of wood type, low-REA cooks required about $20 \%$ less effective alkali than high-REA ones to achieve the target kappa values. Among the various woods, E. globulus was the easiest to delignify. There was a trend to higher brown 
pulp screen yields for the cooks terminated at higher kappa number, in the range of 14-26, but the lignin-HexA free screen yields were about similar in the kappa range of 18-26. At 18 \pm 1 kappa, the low-REA cooks showed higher pulp yield $(1.0 \%)$, xylan yield $(0.8 \%)$, cellulose yield $(0.2 \%)$ and viscosity $\left(90 \mathrm{dm}^{3} \cdot \mathrm{kg}^{-1}\right)$, in relation to the highREA ones. There was a trend for higher preservation of pulp MeGlcA and lower formation of HexA in the low-REA cooks, with the opposite occurring for the high-REA ones. Low-REA cooks produced pulps of lower brightness.

\section{ACKNOWLEDGEMENTS}

I would like to express my sincere gratitude to the CAPES-EMBRAPA Project "Biorefinery of Lignin" for the fellowship.

\section{REFERENCES}

ACHREN, S.; HULTHOLM, T.; LÖNNBERG, B.; KETTUNEN, A.; JIANG, J. E.; HENRICSON, K. Improved pulp yield by optimized alkaline profiles in kraft delignification of birch wood. In: Proceedings of the Tappi Breaking the Pulp Yield Barrier Symposium. 1998. p. 91.

AURELL, R.; HARTLER, N. Kraft pulping of pine. Part I. The changes in the composition of the wood residue during the cooking process. Sven. Papperstidn., v. 68, n. 3, p. 59-68, 1965.

BERGNOR-GIDNERT, E. Influence on pulp quality of conditions during the removal of hexenuronic acids. Nordic Pulp \& Paper Research Journal, v. 13, n. 4, p. 310-316, 1998.

CARVALHO, M. G.; FERREIRA, P. J.; FIGUEIREDO, M. M. Cellulose depolymerisation and paper properties in $E$. globulus kraft pulps. Cellulose, v. 7, n. 4, p. 359-368, 2000.

COLODETTE, J. L. Method of digesting wood with an alkaline liquor by adding an acidic agent to precipitate dissociated lignin. U.S. Patent n. 6,464,827, 15 out. 2002.

COLODETTE, J. L., GOMIDE, J. L., LONGUE JUNIOR, D..; GOMES, C. M. Effect of pulp delignification degree on fiber line performance and bleaching effluent load. BioResources, v. 2, n. 2, p. 223-234, 2007.

COLODETTE, J. L.; GOMES, F. J. B. A novel approach for maximizing eucalypt kraft pulp yield and bleachability. J-FOR-JOURNAL OF SCIENCE \& TECHNOLOGY FOR FOREST PRODUCTS AND PROCESSES, v. 4, n. 5, p. 38-44, 2014.

COLODETTE, J. L.; GOMIDE, J. L.; GIRARD, RUSSELL.; JÄÄSKELÄINEN, A. S.; ARGYROPOULOS, D. S. Influence of pulping conditions on eucalyptus kraft pulp yield, quality, and bleachability. Tappi Journal, v. I, n. I, p. I4-20, 2002.

COSTA, M. M.; COLODETTE, J. L. The impact of kappa number composition on Eucalyptus kraft pulp bleachability. Brazilian Journal of Chemical Engineering, v. 24, n. I, p. 6I-7I, 2007.
GOMES, C. M.; MOKFIENSKI, A.; MOUNTEER, A.; COLODETTE, J. L. Can lignin precipitate during kraft pulping and washing? In: ISWPC International symposium on wood and pulping chemistry, $\mid \mathrm{I}^{\text {th }}$., Nice, 200I. Proceedings... France: Nice, p.337-340, 200 I.

GOMES, V. J.; LONGUE JUNIOR, D.; COLODETTE; J. L.; RIBEIRO, R. A. The effect of eucalypt pulp xylan content on its bleachability, refinability and drainability. Cellulose, v. 2I, n. I, p. 607-6I4, 2014.

GOMIDE, J. L.; COLODETTE, J. L.; ALMEIDA, D. P.; SILVA, C. M. "Kraft pulping of eucalyptus to the optimum technical and economical level," In: $\mathbf{5}$ th International Colloquium on Eucalyptus Pulp, May 9-I2, 20 I I. Porto Seguro, Bahia, Brazil.

GOMIDE, J. L.; COLODETTE, J. L.; OLIVEIRA, R. B.; SILVA, C. M. Caracterização tecnológica, para produção de celulose, da nova geração de clones de Eucalyptus do Brasil. Revista Árvore, v. 29, n. I, 2005.

GOYAL, G. C. "Impact of residual effective alkali (REA) on the bleachability of Kraft hardwood and softwood pulps," In: International Pulp Bleaching Conference, August 2830, 2017 . Porto Seguro, Bahia, Brazil.

GULLICHSEN, J. and FOGELHOLM, C. J. Chemical Pulping, Papermaking science and Technology, 2000. p. 4 II.

GUSTAVSSON, C. On the interrelation between kraft cooking conditions and pulp composition. 2006. Tese de Doutorado. KTH, Stockholm.

HANNA, K.R.; FISHER, J.J. International Pulp Bleaching Conference Proceedings, TAPPI PRESS, Atlanta, Georgia, Book 2, p.323-328, 1998

HANSSON, J.; HARTLER, N. 1969. Sorption of hemicelluloses on cellulose fibres. Part I. Sorption xylans. Svensk Papperstidn., v. 72, n. 17, p. 521-530, 1969.

HARTLER, N. and NORRSTRÖM, H. Light-absorbing properties of pulp and pulp components. III Kraft pulp. Tappi, v. 52, n. 9, p. 1712-1715, 1969.

HUTTERER, C.; FACKLER, K.; POTTHAST, A. The Fate of 4-O-Methyl Glucuronic Acid in Hardwood Xylan during Alkaline Extraction. ACS Sustainable Chemistry \& Engineering, v. 5, n. 2, p. 1818-1823, 2017.

HUTTERER, C.; SCHILD, G.; POTTHAST, A. A precise study on effects that trigger alkaline hemicellulose extraction efficiency. Bioresource technology, v. 214, p. 460-467, 2016.

LI, J.; GELLERSTEDT, G. The contribution to kappa number from hexeneuronic acid groups in pulp xylan. Carbohydrate Research, v. 302, n. 3-4, p. 213-218, 1997.

MACLEOD, Martin. The top ten factors in kraft pulpyield. Paperi Ja Puu/Paper \& Timber, v. 89, n. 7, p. 417, 2007. 
MAGATON, A. S.; COLODETTE, J. L.; GOUVÊA, A. D. F. G.; GOMIDE, J. L.; MUGUET, M. C. S.; PEDRAZZI, C. Eucalyptus wood quality and its impact on kraft pulp production and use. Tappi J, v. 8, p. 32-39, 2009.

MAGATON, A. S.; OLIVEIRA, R.; LOPES, O. R.; MILAGRES, F. R.; PILÓ-VELOSO, D.; COLODETTE, J. L. Composição química da madeira de espécies de eucalipto. $29^{\mathrm{a}}$ Reunião Anual da Sociedade Brasileira de Química, p. 75-106, 2006.

MAGATON, A. S.; PILÓ-VELOSO, D.; COLODETTE, J. L. Characterization of O-acetil-(4-O-methylglucurono) xylans from Eucalyptus urograndis. Química Nova, v. 3 I, n. 5, p. 1085-I088, 2008.

MONRROY, M.; MENDONCA, R.; RODRIGUEZ, J.; BAEZA, J., \& FREER, J. Effect of pulping conditions on the amount of methylglucuronic and hexenuronic acids in kraft pulps of Eucalyptus globulus. Appita Journal: Journal of the Technical Association of the Australian and New Zealand Pulp and Paper Industry, v. 6I, n. 3, p. 2I 2, 2008.

NESSELRODT, K.; LEE, S.; ANDREWS, J. D.; HART, P. W. Mill study on improving lime kiln efficiency. TAPPI JOURNAL, v. I4, n. 2, p. 133-139, 2015.

NIEMINEN, K.; PAANANEN, M.; SIXTA, H. Kinetic model for carbohydrate degradation and dissolution during kraft pulping. Industrial \& Engineering Chemistry Research, v. 53, n. 28, p. II292-II302, 2014.

PINTO, P. C.; EVTUGUIN, D. V.; NETO, C. P. Structure of hardwood glucuronoxylans: modifications and impact on pulp retention during wood kraft pulping. Carbohydrate Polymers, v. 60, n. 4, p. 489-497, 2005.

RENCORET, J.; GUTIERREZ, A.; JOSÉ, C. Lipid and lignin composition of woods from different eucalypt species. Holzforschung, v. 6I, n. 2, p. I65-174, 2007.

SANTIAGO, A. S. V. M. Estratégias para o aumento da retenção de polissacarídeos durante a produção de pasta kraft de Eucalyptus globulus. 2008.

SANTIAGO, A. S.; NETO, C. P. Eucalyptus globulus kraft process modifications: Effect on pulping and bleaching performance and papermaking properties of bleached pulps. Journal of Chemical Technology \& Biotechnology, v. 83, n. 9, p. |298-| 305, 2008.

SANTOS, R. B.; CAPANEMA, E. A.; BALAKSHIN, M. Y.; CHANG, H. M.; JAMEEL, H. Lignin structural variation in hardwood species. Journal of agricultural and food chemistry, v. 60 , n. 19, p. 4923-4930, 2012.

SEGURA, T. E. S.; SANTOS, J. R. S.; SARTO, C.; Silva J. F. G. Effect of Kappa Number Variation on Modified Pulping of Eucalyptus. BioResources, v. II, n. 4, p. 9842-9855, 2016.

SJOSTROM, Eero. Wood chemistry: fundamentals and applications. Gulf professional publishing, 1993. 